\title{
Antibiotic Sensitivity Pattern and Characterization of Staphylococcus aureus for Thermonuclease gene (nuc) in Bovine Affected with Mastitis from Cauvery Delta Region of Tamilnadu, India
}

\author{
R. Manickam*, T. Lurthu Reetha and B. Puvarajan \\ Department of Veterinary Microbiology, Veterinary College and Research Institute, \\ Orathanadu, Tamil Nadu, India \\ *Corresponding author
}

A B S T R A C T

\begin{tabular}{|c|}
\hline Keywords \\
\hline $\begin{array}{l}\text { Cattle, Bovine } \\
\text { Mastitis, } \\
\text { Staphylococcus } \\
\text { aureus, Antibiotic } \\
\text { Resistance, PCR }\end{array}$ \\
\hline Article Info \\
\hline $\begin{array}{l}\text { Accepted: } \\
\text { 04 July } 2019 \\
\text { Available Online: } \\
10 \text { August } 2019\end{array}$ \\
\hline
\end{tabular}

\section{Introduction}

Bovine mastitis is an inflammation of the udder associated with physical, chemical and bacteriological changes in milk. Generally, mastitis occurs in two forms which include clinical and subclinical form. In the clinical mastitis all the five cardinal signs of udder
Among the various mastitis pathogens, Staphylococcus aureus ( $S$. aureus) is identified as a chief etiological agent responsible for subclinical and chronic mastitis. Samples were collected from the clinically affected cattle showing typical symptoms of mastitis. 156 samples were screened by clinical symptoms specific for mastitis from the delta region of Tamilnadu. On the basis of cultural and biochemical properties, 52 isolates were presumptively identified as $S$. aureus. These 52 isolates were subjected to antibiotic sensitivity test, for which 15 antibiotic discs were used. The antibiotic sensitivity pattern of the used antibiotics of the 52 Staphylococcal isolates revealed maximum resistance for pencillin-G (90\%), ampicillin (83\%), erythromycin (60\%), terramycin (54\%), Ampicillin/ Cloxacillin (47\%) and cotrimaxazole $(46 \%)$. whereas, the isolates were highly sensitive to chloramphenical $(84 \%)$, enrofloxacin $(75 \%)$, ofloxacin $(61 \%)$, ceftriaxone $(45 \%)$, and amoxicillin + clavulanic acid $(50 \%)$. All the isolates were susceptible to Vancomycin (100\%). Intermediate pattern was observed in ceftrioxone (14\%), ofloxacin (40\%) and gentamicin (30\%). These 52 isolates were genotypically identified as $S$. aureus by Polymerase Chain Reaction (PCR) for species specific thermonuclease gene $(n u c)$. Amplification for thermonuclease $(n u c)$ gene was observed in 52 solates. The amplified products were of nearly $279 \mathrm{bp}$ when resolved in gel electrophoresis. The phenotypic and genotypic findings of the present study might help to understand the distribution of prevalent $S$. aureus infection in the dairy farms and antibiotic sensitivity pattern will help to choose most appropriate antibiotic, hence help to adopt appropriate strategies for the management and control of bovine mastitis. 
disposal of contaminated milk after treatment and early discard of diseased animals (Gentilini et al., 2002). Clinical mastitis is caused by bacteria and coagulase-positive Staphylococcus aureus is considered a major cause of bovine mastitis. Coagulase negative staphylococci and Corynebacterium bovis, two other highly prevalent pathogens, are historically considered to be of limited importance and are therefore often described as minor pathogens. The impact of Coagulase negative staphylococci is increasing (Pyorala and Taponen, 2009), probably because prevalence of major pathogens is decreasing (Sampimon et al., 2009). Mastitis is one of the major causes imposing the antibiotic use in dairy cows (Mitchell et al., 1998). Approximately $70 \%$ of the antimicrobials applied in dairy production are used for treatment of clinical mastitis (Thomson et al., 2008), but the cure rates for clinical mastitis are not always satisfactorily. The efficacy of bovine mastitis treatment depends on the cause, clinical manifestation, antibiotic susceptibility of etiological agent and the efficiency of immunological system. The abusive or incorrect use of antimicrobials has been implicated as the major selective force for the development of resistance (Levy, 2002).

The bacterial culturing of the raw milk is the standard procedure for diagnosis of the bacterial flora of a particular dairy farm causing intramammary infection, but the method is time consuming. Hence, molecular identification of $S$. aureus by PCR based on their genes is highly conserved throughout bacterial evolution.

Bovine mastitis caused by $S$. aureus is a serious issue because the concern is the increasing antimicrobial resistance and it is more threatening when considering only few antimicrobial agents are available for the treatment. Therefore, the objective of this study is to characterize $S$. aureus phenotypically and genotypically with species specific thermonuclease gene (nuc). The sensitive, intermediate and resistant patterns of the bacterial species isolated from the samples were also recorded.

\section{Materials and Methods}

\section{Collection of milk samples}

One hundred and fifty six samples from the animals showing symptoms of clinical mastitis and positive for CMT were collected from delta region of Tamilnadu. The initial diagnosis of clinical and subclinical mastitis was based on clinical signs and CMT as described earlier (Jain et al., 1971). The sample was processed and the positive animals by CMT point scores were selected for collection of milk samples (Schalm et al., 1957).

The milk samples from affected quarters from each cow were collected after proper disinfection of hand and teat surface with $70 \%$ ethyl alcohol. After teat preparation, about 5$10 \mathrm{ml}$ of milk samples were collected in sterile vials, kept in ice box and carried to the laboratory, where the samples were kept at $4^{\circ} \mathrm{C}$ in refrigerator for bacterial isolation.

\section{Isolation and phenotypic characterization of $S$. aureus}

\section{Bacterial isolation}

The isolation procedures were carried out under strict sterile environment. The identification of causative organism in collected milk samples was carried out (Griffin et al., 1977). The causative organism of the milk samples was identified initially on the basis of colony morphology, zone of hemolysis on $5 \%$ blood agar after $24 \mathrm{hrs}$ post incubation at $37^{\circ} \mathrm{C}$ (Mackie et al., 1960). 


\section{Culture in selective media}

The suspected colonies from 24 to $48 \mathrm{hrs}$ old culture grown in $5 \%$ bovine blood agar were further grown on Mannitol Salt Agar (MSA). The colony characteristics were observed after $24-48$ hours of incubation at $37^{\circ} \mathrm{C}$. Further, the colonies picked from MSA were streaked on Baird Parker media. The suspected samples showing characteristic colony morphology of Staphylococcus spp. were selected for biochemical testing.

\section{Biochemical test of $S$. aureus}

The isolates were subjected to biochemical tests. The biochemical characterization of Staphylococcus aureus was performed by using the commercially available reagents (HiMedia Lab Pvt. Ltd., India). The test contains indole test, methyl red, Voges Proskaeuer's test, ONPG, urease, TSI reaction, arginine utilization and ability to ferment carbohydrate including mannitol, sucrose, maltose, arabinose, raffinose, trehalose, and maltose (Quinn et al., 2004).

\section{Catalase test, Coagulase test and Oxidase test}

Catalase production was detected on nutrient agar slants after $24-72 \mathrm{hrs}$ of incubation by adding 3\% hydrogen peroxide over culture slants (Thomas, 1963). Coagulase test was performed and the positive and negative species were identified (Gillespie, 1943). Oxidase test was performed by filter paper spot method (Kovacs, 1956). The isolates showing biochemical characteristics typical to Staphylococcus species were subjected to polymerase chain reaction.

\section{Antibiotic sensitivity test}

Antibiotic sensitivity pattern of Staphylococcus was carried out by disc diffusion method (Bauer et al., 1966). Briefly, each culture was inoculated into sterilized BHI (Brain-Heart Infusion medium) broth incubated at $37^{\circ} \mathrm{C}$ for $4-6$ hours. The turbidity of the inoculum was compared with 0.5 McFarland standards and the optical density of the suspension was measured by spectrophotometry to be $0.08-0.13$ OD turbid suspension at $620 \mathrm{~nm}$. Pure broth culture of each isolate was spreaded on to the Mueller Hinton agar plates and kept for drying. Antibiotic discs (HiMedia, India) used for the study is depicted in table 2, antibiotic disc were aseptically placed on the dried surface of agar. After incubation, the zone of inhibition was measured in order to ascertain sensitivity of the isolates against the antibiotics.

\section{Genotypic characterization of S. aureus}

\section{Identification of $S$. aureus by PCR}

The isolates were identified as $S$. aureus by amplification of species specific gene. Briefly, for DNA preparation isolates were incubated overnight in $10 \mathrm{ml}$ brain heart infusion broth (BD, USA), centrifuged (5000 g, $15 \mathrm{~min}$ ) and resuspended in $5 \mathrm{ml}$ TE $(10 \mathrm{mM}$ Tris, $1 \mathrm{mM}$ EDTA, pH 8). Total cellular DNA was extracted from 1ml TE with QIAamp DNA Mini Kit (Quiagen, Netherlands) for $G+v e$ bacteria according to manufacturer's protocol. From each sample, $5 \mu \mathrm{l}$ of total cellular DNA was evaluated by PCR (Table 3 ) with primers (Lovseth et al., 2004). The Cycling conditions for amplification: $1 \times 5 \mathrm{~min}$ at $95^{\circ} \mathrm{C}, 1 \mathrm{~min}$ at $95^{\circ} \mathrm{C}, 0.5 \mathrm{~min}$ at $55^{\circ} \mathrm{C}, 1.5 \mathrm{~min}$ at $72^{\circ} \mathrm{C}$, and a final extension at $72^{\circ} \mathrm{C}$ for 7 minutes.

\section{Thermonuclease (nuc) gene}

Species specific primer sequence was employed for the amplification of nuc gene for molecular identification of $S$. aureus (Brakstad et al., 1992). The Cycling conditions for amplification: $1 \times 5 \mathrm{~min}$ at $95^{\circ} \mathrm{C}, 1 \mathrm{~min}$ at 
$95^{\circ} \mathrm{C}, 0.5 \mathrm{~min}$ at $55^{\circ} \mathrm{C}, 1.5 \mathrm{~min}$ at $72^{\circ} \mathrm{C}$, and a final extension at $72^{\circ} \mathrm{C}$ for 7 minutes.

\section{Results and Discussion}

\section{Bacterial isolation}

Out of 156 milk samples, 52 samples revealed growth on $5 \%$ sheep blood agar plates, with zone of hemolysis. Grams' staining of 52 isolates were found as gram positive cocci revealing mannitol fermenting colonies on MSA, which were positive for catalase and negative for oxidase tests (Table 1).

Baird Parker agar plates revealed characteristic black colonies in 52 samples on 24 hours post incubation. The isolated 52 samples were further screened by coagulase test, which revealed viscous clot of rabbit plasma in varying proportions in 27 samples.

\section{Biochemical confirmation of $S$. aureus}

Eighty two isolates were positive for VP, Alkaline Phosphate, Urease, Arginine utilization and ability to ferment carbohydrate including mannitol, sucrose, maltose, trehalose, and negative for ONPG, arabinose and raffinose. They were $(n=52)$ considered as $S$ aureus based on cultural characteristic and biochemical tests.

\section{Antibiotic resistance/susceptibility pattern of Staphylococcal isolates}

The antibiotic sensitivity pattern of the used antibiotics of the 52 Staphylococcal isolates revealed maximum resistance for pencillin-G (90\%), ampicillin (83\%), erythromycin (60\%), terramycin (54\%), Ampicillin/ Cloxacillin $(47 \%)$ and cotrimaxazole $(46 \%)$. whereas, the isolates were highly sensitive to chloramphenical (84\%), enrofloxacin $(75 \%)$, ofloxacin (61\%), ceftriaxone (45\%), and amoxicillin+ clavulanic acid (50\%). All the isolates were susceptible to Vancomycin $(100 \%)$. Intermediate pattern was observed in ceftrioxone (14\%), ofloxacin (40\%) and gentamicin (30\%) (Table 2).

\section{PCR Amplification of Thermonuclease (nuc) gene}

Amplification for thermonuclease (nuc) gene was observed in 52 solates (Figure 1). The amplified products were of nearly 279 bp when resolved in gel electrophoresis.

In the present study, 52 animals were found positive for mastitis, out of 156 animals screened. Genotypically 52 isolates qualified for $S$. aureus infection. Bovine mastitis is one of the most significant causes of economic loss to the dairy industry (Sutra et al., 1994). There is also an increasing public health concern over bovine mastitis because the affected milk is a potential source of pathogens, drug resistant pathogens and antibiotic residue in the human food chain (Mukherjee, 2019).

Mastitis is caused by several pathogens but $S$. aureus is a prime etiologic agent causing intramammary infection in dairy animals in most parts of the world (Mukherjee and Reena, 2006). Many researchers reported staphylococci causing bovine mastitis from northern Indian states (Sharma et al., 2015). $S$. aureus can be recognized phenotypically by a number of ways like Staphylocoagulage test, clumping factor test (Pyorala, 2009) and direct bacteriological examination of milk samples. Moreover, these tests may give positive results for some other species also; hence molecular identification is recognized to be superior to earlier mentioned methods (Tenover, 2006). In present study $86.6 \%$ (52 out of 60 isolates) of the isolates were identified as S.aureus basing on the amplification of nuc gene. nuc gene for identification of $S$. aureus was also identified by some researcher (Brakstad, et al., 1992). 
Table.1 Number of Staphylococcus aureus isolated from the sample

\begin{tabular}{|c|c|c|c|}
\hline $\begin{array}{c}\text { Sl. } \\
\text { no. }\end{array}$ & $\begin{array}{c}\text { No. of Staphylococcus aureus } \\
\text { isolated }\end{array}$ & $\begin{array}{c}\text { Total no of bacterial } \\
\text { isolates }\end{array}$ & Percentage (\%) \\
\hline 1 & 52 & 60 & 86.6 \\
\hline
\end{tabular}

Table.2 Antibiotic sensitivity and resistance pattern of Staphylococcus aureus isolated from bovine mastitic milk samples

\begin{tabular}{|c|c|c|c|c|c|}
\hline \multirow{2}{*}{$\begin{array}{l}\text { Sl. } \\
\text { no. }\end{array}$} & \multirow[t]{2}{*}{ Antibiotic used } & \multirow[t]{2}{*}{ Antibiotic disc } & \multicolumn{3}{|c|}{ Antibiotic sensitivity pattern } \\
\hline & & & $\% \mathbf{R}$ & $\%$ I & $\% \mathrm{~S}$ \\
\hline 1 & Penicillin G & PEN $10 \mathrm{U} /$ disc & 90 & 6 & 4 \\
\hline 2 & Ampicillin & $\begin{array}{l}\text { AMP } 10 \\
\mu \mathrm{g} / \mathrm{disc}\end{array}$ & 83 & 5 & 12 \\
\hline 3 & $\begin{array}{l}\text { Amoxicillin+ clavulanic } \\
\text { acid }\end{array}$ & $\begin{array}{l}\mathrm{AMC} 10 \\
\mu \mathrm{g} / \mathrm{disc}\end{array}$ & 40 & 10 & 50 \\
\hline 4 & Ampicillin/ Cloxacillin & $\begin{array}{l}\text { APX } 30 \\
\mu \mathrm{g} / \mathrm{disc}\end{array}$ & 47 & 25 & 28 \\
\hline 5 & Ceftriaxone & $\begin{array}{l}\text { CTR } 30 \\
\mu \mathrm{g} / \mathrm{disc}\end{array}$ & 41 & 14 & 45 \\
\hline 6 & Ciprofloxaxin & CIP $5 \mu \mathrm{g} / \mathrm{disc}$ & 27 & 40 & 33 \\
\hline 7 & Enrofloxacin & EX $5 \mu \mathrm{g} /$ disc & 22 & 3 & 75 \\
\hline 8 & Ofloxacin & OFX $5 \mu \mathrm{g} /$ disc & 13 & 26 & 61 \\
\hline 9 & Cotrimaxazole & $\begin{array}{l}\text { COT } 25 \\
\mu \mathrm{g} / \mathrm{disc}\end{array}$ & 46 & 25 & 29 \\
\hline 10 & Gentamicin & $\begin{array}{l}\text { GEN10 } \\
\mu \mathrm{g} / \mathrm{disc}\end{array}$ & 27 & 30 & 43 \\
\hline 11 & Erythromicin & $\begin{array}{l}\text { ERY } 15 \\
\mu \mathrm{g} / \mathrm{disc}\end{array}$ & 60 & 18 & 22 \\
\hline 12 & Methicillin & MET $5 \mu \mathrm{g} /$ disc & 19 & 16 & 65 \\
\hline 13 & Terramycin & $\begin{array}{l}\text { TET } 30 \\
\mu \mathrm{g} / \mathrm{disc}\end{array}$ & 54 & 6 & 40 \\
\hline 14 & Vancomycin & $\begin{array}{l}\text { VAN } 30 \\
\mu \mathrm{g} / \mathrm{disc}\end{array}$ & 0 & 0 & 100 \\
\hline 15 & Chloramphenicol & $\begin{array}{l}\text { CHL } 30 \\
\mu \mathrm{g} / \mathrm{disc}\end{array}$ & 10 & 6 & 84 \\
\hline
\end{tabular}

Table.3 Primer sequences used for Thermonuclease gene (nис gene) of Staphylococcus aureus

\begin{tabular}{|c|c|c|c|c|}
\hline Primer Code & Gene & Primer Sequence (5'- 3') & $\begin{array}{l}\text { Amplicon } \\
\text { Size (bp) }\end{array}$ & Reference \\
\hline Nuc F: & nuc & $\begin{array}{l}\text { GCGATTGATGGTGATACGGTT } \\
\text { AGCCAAGCCTTGACGAACTAAAGC }\end{array}$ & 279 & $\begin{array}{l}\text { Brakstad et al., } \\
1992\end{array}$ \\
\hline
\end{tabular}


Fig.1 Agarose gel showing PCR amplified Thermo nuclease (nuc) gene from mastitis milk samples affected with Staphylococcus aureus

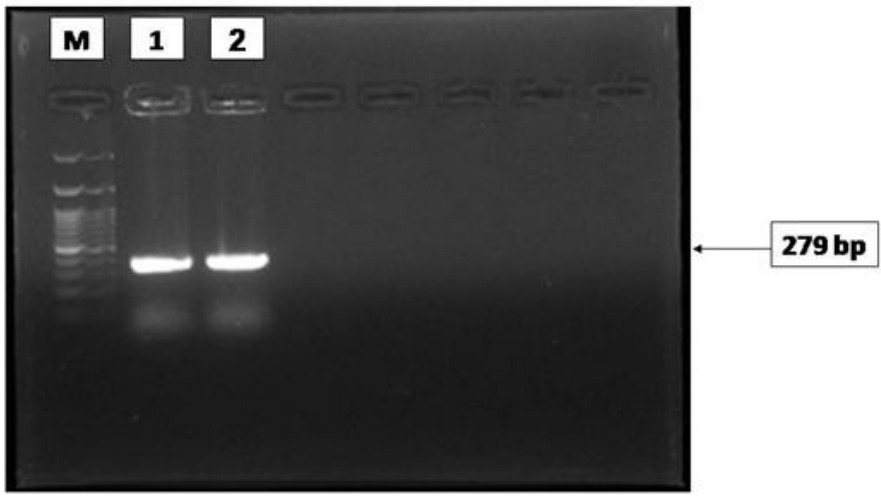

Lane M: 100 bp DNA ladder, Lane 1 and Lane 2: Staphylococcal positive isolate

Mastitis is the most common cause for antibiotic use in dairy herds (Biswas et al., 2014). Antibiotics have been used for the treatment of mastitis but safe, effective and economical treatment is still lacking. Indiscriminate use of antibiotics for the treatment of dairy animals without knowing the antibiotic sensitivity pattern is the causal factor for alarming increase of antibiotic resistance.

In the present study the staphylococcal isolates depicted resistance towards most of the commonly used antibiotics which are being used for the treatment of intramammary infection in dairy cattle.

In the present study used 15 antibiotic discs to study the antibiotic sensitivity pattern of the bacterial isolate. Most of the isolates belonging to multiple drug resistant category, as they were showing resistance for more than three classes of antibiotics. Isolates exhibiting in vitro resistance to three or more than three classes of antimicrobials were classified as multidrug-resistant (Kumar et al., 2010). In our study, maximum resistance was observed against penicillin and ampicillin and the resistance was $\geq 90 \%$, followed by erythromicin, cotrimaxazole, tetracycline and ceftriaxone. Penicillin $\mathrm{G}$ resistance $(85.72 \%)$ among $S$. aureus isolates from mastitis milk samples in Germany (Behiry et al., 2012).

S. aureus develop antimicrobial resistance to most of the commonly used antibiotics and the bacteria acquire the resistance through the horizontal gene transfer (Lindsay, 2014). In the present study, contrary to the above result, remarkably the isolates were showing susceptibility for chloramphenicol, it may be due to this antibiotic is not being in use for considerably long period of time. Similarly the isolates were susceptible to enrofloxacin, methycillin and ampicillin+clavulanic acid although ofloxacin, methycillin and chloramphenicol are also very sensitive but are not used for the treatment of bovine mastitis.

All the isolates were vancomycin susceptible but this antibiotic is never used for the treatment of animal diseases, which is a matter of great concern. The source of acquisition of resistance against these novel antibiotics in these dairy cattle may be from environmental source or dairy workers.

In the present study, 156 cows were screened for mastitis from the Cauvery delta region of Tamilnadu. Fifty two isolates were confirmed as $S$. aureus. Isolates were resistant to 
penicillin, aminopenicills, beta-lactum, macrolide, sulpha and tetracycline class of antibiotics, and susceptible to fluroquinolones, oxazolidone, glycopeptides and extended spectrum betalactum inhibitors. Such kind of study might help to understand the distribution of $S$. aureus infection in the dairy farms and selection of most appropriate antibiotic to adopt appropriate strategies for the management and control of bovine mastitis.

\section{Acknowledgments}

The authors are thankful to the farmers and dairy owners of Cauvery delta region for helping and cooperating for the sample collection. Authors are thankful to the professor and Head, TVCC, VCRI, Orathanadu for providing all the supports in collecting samples for conducting the research work.

\section{References}

Bauer AW, Kirby WM, Sherris JC, Turck M. Antibiotic susceptibility testing by a standardized single disk method. Am J Clin Pathol. 1966; 45 (4): 493-6.

Behiry AE, Schlenker G, Szabo I, Roesler U. In vitro susceptibility of Staphylococcus aureus strains isolated from cows with subclinical mastitis to different antimicrobial agents. J Vet Sci.2012; 13(2): 153-161.

Biswas S, Mukherjee R, Mahto R, De UK, Chakravary S, Bera A K, Deb SM. Antibacterial sensitivity and resistance pattern of yak intramammary infection from Arunachal Pradesh India. Asian J of Animal and Vet Advances. 2014; 9(10): 683-689.

Brakstad O G, Aasbakk K, Maeland JA. Detection of Staphylococcus aureus by polymerase chain reaction amplification of the nис gene. J Clin Microbiol. 1992; 30 (7):1654-1660.
Gentilini, E, G. Denamiel, A. Betancor, M. Rebuelto, M. Rodrigues-Fermepin and R.A. De Torrest, 2002. Antimicrobial susceptibility of coagulase-negative Staphylococci isolated from bovine mastitis in Argentina. Journal of Dairy Science, 85, 1913-1917.

Gillespie E H. The routine use of coagulase test for Staphylococci. Mon Bull Emerg Publ Hlth Lab Serv. 1943; 2: 19.

Griffin TK, Dodd FH, Neave FK, Westgarth DR, Kingwil RG, Wilson CD. A Method of diagnosing intramammary infection in dairy cows for large experiments. J Dairy Res. 1977; 44(1): 25-45.

Jain NC, Schalm OW, Lasmanis J. Experimentally induced coliform (Aerobacter aerogenes) mastitis in normal cows and in cows made neutropenic by an equine anti-bovine leukocyte serum. Am J Vet Res. 1971; 32(12): 1929-35.

Kovacs N. Identification of Pseudomonas pyocyanea by oxidase reaction. Nature. 1956; 178(4535): 703.

Kumar A, Anu Rahal, Dwivedi, SK. Gupta MK. Bacterial prevalence and antibiotic resistance profile from bovine mastitis in Mathura, India. Egyptian Journal of Dairy Science. 2010; 38(1): 31-34.

Levy, S. B., 2002. The antibiotic paradox: how the misuse of antibiotics destroys their curative powers. 2 Ed. Cambridge Mass Perseus Publishing, ISBN 9780738204406, 353.

Lindsay JA. Staphylococcus aureus genomics and the impact of horizontal gene transfer. Int J Med Microbiol. 2014; 304(2): 103-9. doi: 10.1016/j.ijmm.2013.11.010.

Lovseth A, Loncarevic S, Berdal K G. Modified multiplex PCR Method for detection of pyrogenic exotoxin genes in Staphylococcal isolates. $\mathbf{J}$ Clin Microbiol. 2004; 42(8): 3869-3872. doi: 
10.1128/JCM.42.8.3869-3872.2004.

Mackie TJ, McCartney JE. Mackie and Mc Cartney's Handbook of Bacteriology. 10th ed. Cruickshank R, editor. London: E. \& S. Livingstone limited; 1960.

Mitchell, J. M., M. W. Griffiths, S. A. McEwen, W. B. McNab and A. J. Yee, 1998. Antimicrobial drug residues in milk and meat: Causes, concerns, prevalence, regulations, tests, and test performance. J. Food Prot, 61, 742-756.

Mukherjee $\mathrm{R}$ and Reena. Assessment of reactive oxygen species and phagocytosis of milk leukocytes by alfa-tocopherol and enrofloxacin in bovine mastitis. Veternarski Arhiv. 2006; 76(1): 1-9.

Mukherjee R. Dynamics of milk leukocytes in response to a biological response modifier during bovine subclinical mastitis. Res Vet Sci. 2013; 95(2): 3527. doi: 10.1016/j. rvsc.2013.06.010.

Pyorala S. Treatment of mastitis during lactation. Ir Vet J. 2009; 62(4):40-44.

Pyorala, S. and S. Taponen, 2009. Coagulasenegative staphylococci - emerging mastitis pathogens. Veterinary Microbiology, 134 (1-2), pp. 3-8.

Quinn PJ, Carter ME, Markey B, Carter GR. Clinical Vet Microbiol.2nd ed. St Louis: Mosby; 2004. p. 118-125.

Sampimon, O, W. Barkema, I. Berends, J. Sol and T. Lam, 2009. Prevalence of intramammary infection in Dutch dairy herds. Journal of Dairy Research, 76
(2), 129-136.

Schalm OW, Noorlander DO. Experiment and observation leading to the development of the California mastitis test. J Am Vet Med Assoc. 1957; 130(5): 199-204.

Sharma L, Verma AK, Kumar, Rahat A, Neha, Nigam R. Incidence and Pattern of Antibiotic Resistance of Staphylococcus aureus Isolated from Clinical and Subclinical Mastitis in Cattle and Buffaloes. Asian J Anim Sci. 2015; 9(3): 100-109. doi: 10.3923/ ajas.2015.100.109.

Sutra L, Poutrel B. Virulence factors involved in the pathogenesis of bovine intramammary infections due to Staphylococcus aureus. J Med Microbiol. 1994; 40(2): 79-89.

Tenover FC. Mechanisms of antimicrobial resistance in bacteria. Am J Med. 2006; 119(6 Suppl 1): S3-10; discussion S6270.

Thomas K. A blue peroxide slide catalase test. Mon Bulll Emerg Publ Hlth Lab Serv. 1963; 22: 124-125.

Thomson, K., M. Rantala, M. Hautala, S. Pyorala and L.Kaartinen, 2008. Crosssectional prospective survey to study indication - based usage of antimicrobials in animals: Results of use in cattle, http://www.biomedcetral.com/17466148/4/15/, BMC Veterinary Research, 4-15.

\section{How to cite this article:}

Manickam, R., T. Lurthu Reetha and Puvarajan, B. 2019. Antibiotic Sensitivity Pattern and Characterization of Staphylococcus aureus for Thermonuclease gene (nuc) in Bovine Affected with Mastitis from Cauvery Delta Region of Tamilnadu, India. Int.J.Curr.Microbiol.App.Sci. 8(08): 192-199. doi: https://doi.org/10.20546/ijcmas.2019.808.023 